\title{
MODEL ROTASI KERJA MEMPERTIMBANGKAN FAKTOR KEBOSANAN
}

\author{
Nitabian Iftita Rahayu \\ Fakultas Teknik Industri, \\ Universitas PGRI Adi Buana Surabaya \\ email: nitabian_cute@yahoo.co.id
}

\begin{abstract}
Memasuki dunia global seperti saat ini, pengembangan sumber daya manusia perlu mendapat perhatian, karena tidak jarang kinerja karyawan mengalami fluktuasi. Fluktuasi kinerja merupakan permasalahan yang banyak dihadapi oleh perusahaan lorganisasi. Apabila hal ini berulang secara terus-menerus dan tidak ada pengendalian yang baik oleh perusahaan maka akan berdampak pada produktivitas dan pencapaian tujuan lainnya. Faktor penyebab fluktuasi kinerja karyawan diantaranya adalah kesalahan penempatankaryawanpadatugaskerjadanfaktorkebosanan yang dialami oleh karyawan.Pendekatanyang efektif untuk permasalahan ini salah satunya adalah dengan rotasi kerja.Oleh sebab itu, penelitian ini bermaksud membuat suatu model rotasi kerja dengan kebosanan sebagai faktorpertimbangan. Secara garis besar penelitian terbagi menjadi tiga tahapan yaitu tahap penelitian pendahuluan, tahap pembuatan model matematis, dan tahap percobaan numerik. Penelitian ini menggunakan integer programming dengan produktivitas sebagai fungs itujuan. Hasil percobaan numerik menunjukkan bahwa rotasi kerja yang mempertimbangkan faktor kebosanan memberikan hasil yang baik dari segi produktivitas dan fungsi kendala.
\end{abstract}

Keywords: Manajemen Sumber Daya Manusia, Kinerja Karyawan, Rotasi Kerja, Kebosanan, Integer Programming

\section{PENDAHULUAN}

Sumber daya manusia merupakan sumber utama keunggulan kompetitif dan kompetensi yang dimiliki oleh organisasi/perusahaan (SaravanidanAbbasi, 2013). Kebijakan pengelolaan sumber daya manusia perlu ditingkatkan karena kinerja karyawan mengalami kenaikan dan penurunan. Kinerja adalah suatu prestasi kerja atau hasil kerja karyawan yang terukur secara kuantitas ataupun kualitas. Fluktuasi kinerjaini dapat mempengaruhi produktivitas dan tujuan lain yang ingin dicapai perusahaan. Eiseltdan Marianov (2008) menyatakan bahwa menurunnya kinerja karyawan dipengaruhi oleh salah penempatan karyawan pada tugas kerja tertentu. Karyawan mengalami bebankerja yang tinggiakibat kurangnya keseimbangan antarakemampuan atau skill yang dimiliki dengan tugas kerja yang diterima. Sedangkan menurutAzizi (2009) dan Jahandideh (2012) menurunnya kinerja disebabkan oleh kebosanan karyawan.

Kebosanan (boredom) adalah factor ergonomi pada manusia (human factors) yang dapat mempengaruhi produktivitas, yang didefinisikan sebagai suatu keadaan kurang berminat yang dialami oleh setiap individu karyawan terhadap pekerjaannya (Rahayu, 2015). Kebosanan dapat pula didefinisikan sebagai kurangnya ketangkasan mental karyawan dalam bekerja atau bereaksi positif terhadap pekerjaannya (Jahandideh, 2012). Menurut beberapa penelitian, faktorfaktor yang dapat mempengaruhi kebosananantara lain pekerjaan yang berulang (repetitive) dan monoton (Azizi, 2009;Pardede, 2009; Jahandideh, 2012; Susihono, 2014); faktor individu, faktor lingkungan kerja dan faktor pekerjaan/ tugas kerja (Anastasi, 1989).

Rotasi kerja merupakan salah satucara yang efektif untuk mengelola sumber daya manusia, yaitu dengan cara mengalokasikan karyawan dari work station satu ke work station lain, atau daritugas kerja satu ke tugas kerja yang lain dalam periode waktu tertentu. Kaymaz (2010) menyatakan bahwa rotasi kerja memiliki dampak yang positif terhadap motivasi, meningkatkan moral dan interaksi sosial antarkaryawan, meningkatkan pengetahuan dan kompetensi, mengurangi kebosanan dan sebagai saranaperbaikan secara terus-menerus. 
Penelitian ini bermaksud untuk mengembangkan suatu model rotasikerja dengan mempertimbangkan faktor kebosanan.

\section{METODE}

Penelitian dilakukan melalui tiga tahap, yaitu penelitian pendahuluan, formulasi model matematis, dan tahap percobaan numerik.

\section{Tahap Penelitian Pendahuluan}

Pada tahap ini dilakukan studi literatur dari penelitian terdahulu yang terkait dengan rotasi kerja guna mendapatkan celah penelitian dan data.

\section{TahapFormulasi Model Matematis}

Formulasi model matematis meliputi tiga tahapan yaitu :

a. Penetapannilai parameter

Parameter yang ditetapkan adalah data mengenai nilai kerjakaryawan, alokasi karyawan sesuai dengan kebutuhandan skill, dan parameter kebosanan.

b. Perumusan model matematis

Fungsi tujuan dan fungsi kendala dalam penelitian ini adalah modifikasi dari Wongwien dan Nanthavanij dalam Setiawan (2014) dan Rahayu, 2015. Secara keseluruhan fungsi tujuan dan fungsi kendala dalam penelitian ini adalah sebagai berikut :

1) Fungsi tujuan adalah memaksimumkan produktivitas /nilai kerja karyawan.

$\operatorname{Max} \sum_{i=1}^{I} \sum_{j=1}^{J} \sum_{k=1}^{K} S_{i j} x X_{i j k}$

dengan :

$\mathrm{I}=$ jumlah karyawan, $i \in\{1,2, \ldots . I\}$

$\mathrm{J}=$ jumlah tugas kerja, $j \in\{1,2, \ldots . J\}$

$\mathrm{K}=$ periode kerja, $k \in\{1,2, \ldots . K\}$

$S_{i j}=$ produktivitas karyawan i ketika melakukan tugas kerja $\mathrm{j}$

$X_{i j k}=\quad$ bernilai 1 jika karyawan i dialokasikan pada tugas kerja $\mathrm{j}$ pada periode $\mathrm{k}$, dan 0 jika sebaliknya.

2) Fungsi kendala :

- Alokasi karyawan pada periode kerja
$\sum_{j=1}^{J} X_{i j k} \leq$

$1 \forall i, k$

- Keseimbangan kebutuhan antara karyawan dan tugas kerja

$\sum_{i=1}^{I} X_{i j k} \leq W_{j} \quad \forall j, k$

- Keseimbangan antara skill dan tugas kerja

$X_{i j k} \leq a_{i j} \quad \forall i, j, k$

- Kebosanankaryawan

$\sum_{k=1}^{K} X_{i j k} \leq t_{i j} \quad \forall i, j$

3) Variabelkeputusan

$$
X_{i j k}, Y_{i} \in\{0,1\} \quad \forall i, j, k
$$

Dimana :

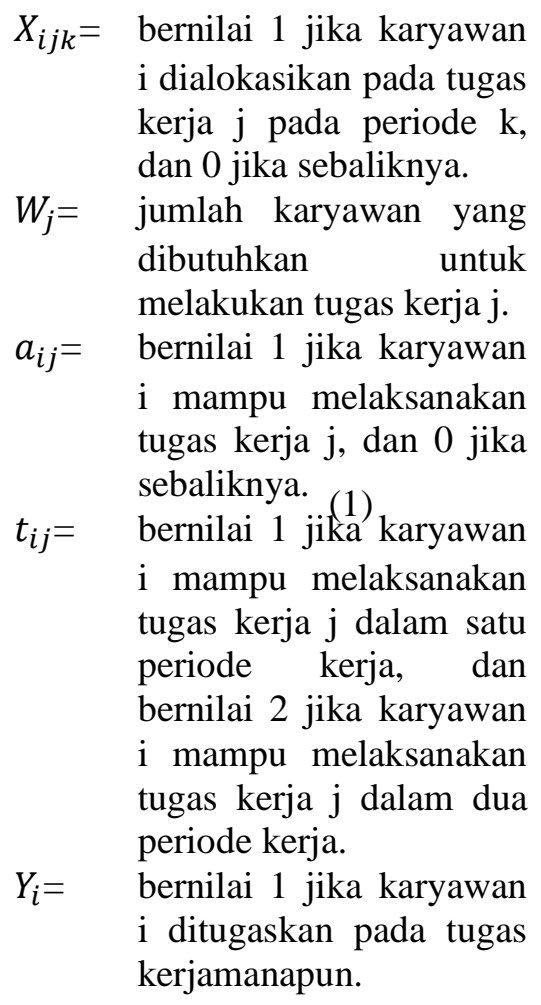

c. Uji verifikasi dan validasi

Ditahap ini dilakukan uji verifikasi dan validasi terhadap model yang dikembangkan dengan menggunakan software LINGO. 


\section{Tahap Percobaan Numerik}

Tahapan terakhir dilakukan percobaan numerik, analisis hasil percobaan, dan simulasi terhadap model yang dikembangkan.

\section{HASIL DANPEMBAHASAN}

Hasil uji verifikasi menunjukkanbahwa model matematis yang dikembangkansesuaidenganformulasibahasa LINGO dengannilaiInfeasibilities= 0.000000 dan nilai produktivitas $=20,1$. Hal iniberarti model terverifikasi. Sedangkan hasil uji validasi menunjukkan bahwa nilai produktivitas dari perhitungan manual adalah sama dengan nilai produktivitas dari perhitungan software, yaitu 5,4. Sehingga bias dikatakan bahwa model telah tervalidasi.

Dari hasil running LINGO diketahui bahwa produktivitas atau total nilai kerja pada model ini adalah 25. Jika dilihat dari batas kendala kebosanan, setiap karyawan memilik inilaiduadanterpenuhisemua.Hal inimenunjukkanbahwasetiapkaryawanmamp umengerjakanpekerjaannyadalamduaperiode kerja.

Hasil simulasi model rotasi kerja mempertimbangkan factor kebosanan dapat dilihat padaGambar 1 dan Gambar 2 berikut.
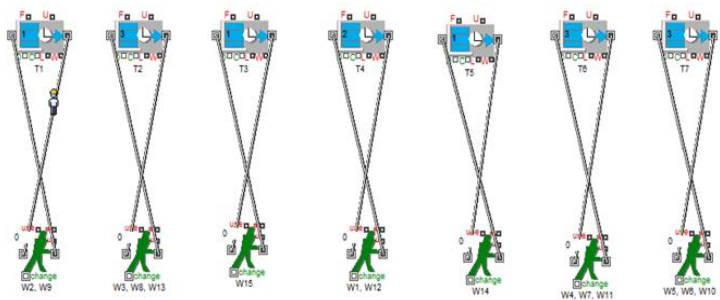

Gambar 1 Representasi Simulasi Model Pada Periode Pertama

Pada periode pertama, karyawan (W2 dan W9) mengerjakan tugas kerja (T1), karyawan (W3, W8, dan W13) mengerjakan tugas kerja(T2), karyawan (W15) mengerjakan tugas kerja (T3), karyawan (W1 dan W12) mengerjakan tugas kerja (T4), karyawan (W14) mengerjakan tugas kerja (T5), karyawan (W4, W7, dan W11) mengerjakan tugas kerja (T6), dan karyawan (W5, W6, dan W10) mengerjakan tugas kerja (T7).
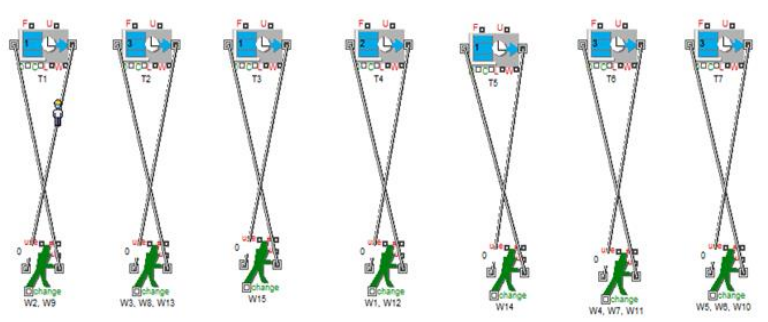

sebagaimana terlihat pada Gambar 1 dan Gambar 2 di atas. Tidak ada karyawan maupun tugas kerja yang idle karena fungsi kendala kebosanan terpenuhi semua. Sehingga diperoleh total nilai kerja atau produktivitas yang tinggi.

\section{KESIMPULAN}

Dari hasil percobaan numerik diketahui bahwa model rotasi pekerjaan yang mempertimbangkan factor kebosanan memberikan hasil yang baik dilihat dari fungsi kendala dan produktivitas, semua terpenuhi. Sedangkan, dari simulasi dihasilkan penjadwalan rotasi kerja berupa rincian tugas kerja karyawan pada tiap work station selama dua periode kerja.

Adapun saran yang dapat peneliti berikan, antara lain:

a. Diperlukan adanya pengembangan fungsi tujuan yang lebih komprehensif

b. Pengembangan metode selain metode yang digunakan dalam penelitian ini

c. Pengukuran interval rotasi pekerjaan yang didasarkan pada trade off akibat proses learning and forgetting.

\section{REFERENSI}

Anastasi, A. (1989), Bidang-Bidang Psikologi Terapan. Penerbit: Rajawali Press, Jakarta.

Azizi, N. (2009), Manufacturing Productivity Improvement: A Study of Human Boredom, Job Rotation and Scheduling. Disertasi Ph.D., University of Ottawa, Ontario, Canada.

Eiselt, H.A. danMarianov, V. (2008), "Employee positioning and workload allocation".Computers and Operations Research, Vol. 35, hal.513-524.

Jahandideh, S. (2012), Job Scheduling Considering Both Mental Fatique and 
Boredom. Thesis, University of Ottawa, Ottawa.

Kaymaz, K. (2010), "The effects of job rotation practices on motivation: a research on managers in the automotive organizations". Business and Economics Research Journal, Vol. 1, No. 3, hal.69-85.

Pardede, Y.O.K. (2009), "Kebosanan Kerja pada Karyawan Pabrik Unit Peleburan”. JurnalPsikologi, Vol. 2, No. 2.

Rahayu, N.I. (2015), Model Rotasi Pekerjaan Berdasarkan Faktor Ergonomi. Tesis, Institut Teknologi Sepuluh Nopember Surabaya.

Saravani, S.R. danAbbasi, B. (2013), "Investigating the influence of job rotation on performance by considering skill variation and job satisfaction of bank employees".Int. J. Technical Gazette, Vol.20, hal.473478.

Setiawan, D. (2014), Model penjadwalan tenaga kerja mempertimbangkan factor ergonomi. Tesis, Institut Teknologi Sepuluh Nopember Surabaya.

Susihono, W. (2014), “Assessment kebosanan kerjakaryawan sebagai dasar evaluasi kinerja aspek task, organisasi dan lingkungan perusahaan; studi kasus di kawasan industry TangerangBanten". Simposium Nasional, RAPI XIII-FT UMS. 